УСТИНКИН Сергей Васильевич - доктор исторических наук, профессор; декан Высшей школы экономики и мировой политики Нижегородского государственного лингвистического университета им. Н.А. Добролюбова (603155, Россия, г. Нижний Новгород, ул. Минина, 31A; sv.ustinkin@gmail.com) ГАСЕМ Ахмед - аспирант Нижегородского государственного лингвистического университета им. Н.А. Добролюбова (603155, Россия, г. Нижний Новгород, ул. Минина, 31A; ahmed.gacem@таil.ru) РУДАКОВА Екатерина Константиновна - кандидат политических наук; доцент кафедры международных отношений и политологии, старший научный сотрудник Нижегородского государственного лингвистического университета им. Н.А. Добролюбова (603155, Россия, г. Нижний Новгород, ул. Минина, 31A; ekaterina-rudakowa@mail.ru)

\title{
ПРОЦЕСС НАЦИОНАЛЬНОГО ПРИМИРЕНИЯ В АЛЖИРЕ: НОРМАТИВНО-ПРАВОВОЙ И ДЕМОГРАФИЧЕСКИЙ АСПЕКТЫ
}

\begin{abstract}
Аннотация. Статья посвящена рассмотрению этапов нормативно-правового оформления процесса национального примирения в Республике Алжир в период войны за независимость 1991-2002 гг. После первоначального национального диалога власти и политических партий в 1995 г. и проведения национального симпозиума в 1996 г. в Алжире постепенно была создана законодательная база по вопросам безопасности и противодействия терроризму, утверждены меры в отношении бывших террористов, приняты поправки к Конституции, законы «О национальном примирении", “О гражданской гармонии». Несмотря на прекращение массовой гибели мирных граждан и сохранение демографического потенциала страны, до сих пор в Алжире ощутимы серьезные последствия «черного десятилетия»: на юге Алжира продолжают действовать международные террористические группировки, до сих пор в розыске находятся тысячи человек, а жертвы насилия ждут материальных компенсаций.
\end{abstract}

Ключевые слова: Республика Алжир, терроризм, национальное примирение, демография

$\Pi$ роцесс национального примирения в Алжире является результатом долгих и затяжных попыток нормативно-правового регулирования и политического диалога. Термин «национальное примирение», который используется в законодательстве Алжира, является окончательным для определения фазы установления внутреннего мира в Республике Алжир. Национальный диалог как инструмент достижения национального примирения был единственно возможным механизмом в самом начале кризиса, активно использовался политическими деятелями и представителями политических партий, призывавших к реализации проекта национального примирения. Среди них можно назвать основные партии, которые одержали победу на выборах 1991 г. в законодательные органы власти Республики Алжир: Исламский фронт спасения, Фронт национального освобождения, Фронт социалистических сил и др. Тем не менее избранный путь национального диалога не позволил достичь желаемой стабильности, политический и общественный разрыв увеличился, а ситуация с безопасностью ухудшилась. В этот период, 22 июня 1992 г., был убит президент Алжира Мухаммед Будиаф - спустя несколько месяцев после того, как он стал председателем Верховного государственного совета Алжира. В связи с убийством лидера страны партия «Исламский фронт спасения» обвинила некоторых членов Верховного совета Алжира в «лояльности масонству» и «защите сионистской мысли».

Процесс национального примирения в Алжире прошел несколько стадий нормативно-правового оформления.

Первой стадией стал политический диалог. В 1995 г. алжирские партии про- 
вели встречу в Риме и подписали первое письменное соглашение «О национальном примирении». Как альтернатива политическому диалогу стал возможным политический диалог с властью политических партий Алжира. Римская контактная группа охарактеризовала начавшийся политический диалог меткой фразой: «Нет диалога одних против других». Абдель Хамид Махри, бывший генеральный секретарь Фронта национального освобождения, также выразил мнение, что проект примирения должен стать национальным консенсусом среди всех политических сил, влияющих на общество, так же, как и поиск решения проблем, вызвавших кризис. Далеко не все партии приняли участие в диалоге: например, партия «Исламский фронт спасения» не стала партнером власти в обсуждении проблем мира и безопасности, хотя и высказывала озабоченность кризисом в стране. Можно сказать, что, несмотря на все усилия по урегулированию кризиса, первая попытка политического диалога не завершилась серьезным обсуждением назревших проблем, но подвела к идее проведения симпозиума национального согласия, который хотя и не улучшил безопасность и политическую стабильность в стране, и многие стали говорить о провале национального примирения по причине не полного состава участников от политических партий, но, тем не менее, стал отправной точкой для дальнейшей политики укрепления мира в Республике Алжир [Ханун 2008].

Вторая стадия связана с законом «О милосердии» и национальным симпозиумом. Закон «О милосердии» был принят 25 февраля 1995 г.; он состоял из 12 статей и 3 глав и считался поправкой к Уголовному кодексу Алжира, особенно в части определения террористических преступлений и предусмотренных для них мер наказания. Данный закон был призван восстановить мир, стабильность, безопасность, процветание, уважение к закону и государству, должен был положить конец кровопролитию. Необходимо отметить, что закон стал первым нормативно-правовым документом, согласованным в ходе политического диалога о примирении, отправной точкой для принятия дальнейших национальных мер по урегулированию политического кризиса ${ }^{1}$.

7 июля 1996 г. премьер-министр Алжира Ахмед Уяхия представил итоги программы национального примирения в Национальный суд и Национальный переходный совет, сосредоточив внимание на сложной социально-политической ситуации и борьбе с коррупцией. По итогам выступления правительство Алжира провело многосторонние встречи. В то же самое время возросло недовольство международным вмешательством со стороны левого политического сектора: Фронт национального освобождения объявил о полном разрыве с «римской платформой» урегулирования кризиса. 14 августа 1996 г. четыре комитета начали работать в дополнение к 29 партиям: первый комитет обсуждал симпозиум по национальному согласию, второй - вопросы принятия поправок к Конституции, третий - принятие закона о политических партиях, а четвертый - вопросы избирательного права. 14 сентября 1996 г. президент Алжира Ламин Зеруаль открыл симпозиум национального согласия во Дворце наций Алжира. Среди 1000 человек присутствовавших были представители государственных учреждений, 37 неправительственных организаций, 28 политических партий, включая Фронт национального освобождения и Ренессансное движение, 7 женских ассоциаций, 17 молодежных организаций, алжирская и иностранная пресса. На симпозиуме обсуждались меры по отношению к вооруженным силам, армии, силам безопасности для защиты Алжира от терро-

1 Африка в воспоминаниях ветеранов дипломатической службы. Т. 5(12). М.:Институт Африки РАН. 2004. С. 9. 
ризма и криминального шантажа. 15 сентября 1996 г. во Дворце наций Алжира состоялось заключительное заседание национального симпозиума, результатом которого стало подписание соглашения и определение основных принципов проведения будущего референдума по поправкам к Конституции. 21 сентября 1996 г. президент провел пресс-конференцию, на которой подвел итоги симпозиума, а также затронул вопросы национальной идентичности, ислама и арабизма. В октябре 1996 г. алжирские газеты опубликовали речь президента Ламина Зеруаля, в которой он объявил о проведении 28 ноября 1996 г. референдума по внесению поправок в Конституцию Алжира.

Третья стадия - вопросы системы безопасности и защита от терроризма. Террористические действия с самого начала были направлены против алжирского государства. Национальная алжирская армия выступала против террористической активности и играла важную роль в сохранении государства. Помимо уничтожения террористических групп, силы безопасности Алжира использовали информацию, полученную от захваченных террористов.

В результате 13 июля 1999 г. был принят закон «О гражданской гармонии», целью которого являлось восстановление гражданской гармонии, утверждение специальных мер для лиц, причастных к терактам или саботажу, и тех, кто выражает желание сознательно прекратить свою преступную деятельность. Многие молодые люди, совершившие ранее террористические и подрывные действия, могли быть амнистированы или избежать наказания за ранее совершенные террористические преступления в соответствии с законом «О мерах пощады»; в народе они получили название «раскаявшиеся террористы».

Тем не менее принятые политические меры и нормативные механизмы не разрешили кризис в Алжире, который к тому моменту стал приобретать международный резонанс, поэтому лозунги национального примирения стали основными на выборах президента в 1999 г. Избранный президент Абдель Азиз Бутефлика в свой первый президентский срок сделал ставку на вопросы национального примирения. В этот период алжирский парламент единогласно одобрил закон «О гражданской гармонии», который был представлен на всенародный референдум 16 сентября 1999 г. Результаты референдума продемонстрировали желание людей положить конец кризису, а политика гражданской гармонии должна была быть направлена на восстановление мира и безопасности во всех регионах страны, экономическое и социальное развитие. Концепция национального примирения впервые с 1989 г. стала общим знаменателем для народа, власти и партий Алжира. Основными целями закона были названы соблюдение Конституции, обеспечение применения законов республики и их соблюдение; защита и обеспечение прав жертв терроризма; признание роли государственных институтов. Закон «О гражданской гармонии» содержал и технические вопросы, такие как условия освобождения от судебного преследования, процедуры отсрочки. Позднее возникла необходимость в принятии всеобъемлющего закона «О национальном примирении», который должен был послужить основой для установления национального мира 1 .

Четвертая стадия - закон о национальном примирении. Проект закона национального примирения был представлен президентом Абдель Азизом Бутефликом, который пытался положить конец войне в Алжире. 29 сентября 2005 г. был проведен референдум. Проект был одобрен 97\% голосов, а 28 фев-

${ }^{1}$ Sofiane Choutier. Algeria - Attacks on Justice. - International Comission of Justice. $11^{\text {th }}$ ed. URL: https://www.icj.org/wp-content/uploads/2012/03/algeria_attacks_justice_27_08_2002.pdf (проверено 06.09.2020). 
раля 2006 г. был принят в качестве закона «О национальном примирении» 1 . Основными целями принятия закона стали достижение единства алжирского государства и уважение прав человека, единство армии и системы безопасности, мирное урегулирование кризиса. По мнению экспертов, закон стал лучшим решением многих проблем, наиболее важными из которых являлись поставка оружия и доходы от террористических актов.

Сегодня, несмотря на позитивные сдвиги в деле национального примирения, до сих пор не решен целый ряд сложнейших вопросов:

1) не выплачены компенсации жертвам терроризма и их семьям (более150 000 погибших $)^{2}$;

2) не завершен розыск пропавших без вести в течение «черного десятилетия» (около 6140 чел.);

3) не закончена социальная и политическая интеграция бенефициаров национального примирения.

Тем не менее важнейшим достижением национального примирения является завершение «черного десятилетия», во время которого погибло огромное число мирных жителей Алжира.

Показателем достижения определенных успехов в деле национального примирения является современное демографическое развитие Алжира. Алжир сохранил высокий демографический потенциал для роста и развития страны. Несмотря на драматические события войны, Алжир демонстрирует высокие темпы рождаемости, снижение смертности, растет доля молодого поколения, не вступившего в трудовой возраст, что, с одной стороны, создает большие возможности для будущего экономического развития и преодоления вызовов нового века, с другой - серьезные трудности в сфере обеспечения его рабочими местами. В свете деятельности и прозелитизма радикальных группировок серьезной проблемой станет воспитание подрастающего поколения в духе уважения к национальным ценностям и национального единства, что потребует внедрения специальных программ образования по противодействию распространению радикализма в молодежной среде.

Серьезным демографическим последствием войны стал рост численности населения в среднем на 1 млн чел. в год и взрывной рост городских агломераций. Несмотря на попытки Алжира внедрить западные программы планирования семьи, большинство населения Алжира и соседних стран выступают против изменения традиционных устоев в отношении семейных ценностей. Любая попытка законодательного регулирования сакральной семейной жизни считается нарушением общественных и религиозных норм и неизбежно станет новым поводом для радикализма и нарушения национального согласия [Балмасов 2017].

В среднесрочной перспективе следует ожидать миграционного сценария в Алжире, когда большая часть молодого поколения будет по-прежнему выезжать на заработки в страны с низким демографическим ростом и нехваткой рабочей силы - в Европу, США, Канаду. Они станут основным фактором решения экономических и демографических проблем для этих стран, а это означает, что продолжится не только диалог в сфере совместной антитеррори-

1 Указ Президента Алжира № 06-93 от 27 февраля 2006 г. «О компенсации жертвам национальной трагедии». Доступ: https://www.joradp.dz/HAR/Index.htm (проверено 02.09.2020); Указ Президента Алжира № 06-01 от 27 февраля 2006 г. «Хартия мира и национального примирения». Доступ: https://www.joradp.dz/HAR/Index.htm (проверено 02.09.2020).

2 Algeria puts strife toll at 150,000. - Al Jazeera English. 2005. February 23. Доступ: https:// www.aljazeera.com/archive/2005/02/200849155453867369.html (проверено 02.09.2020). 
стической деятельности, но и диалог межкультурный, межконфессиональный, поскольку мигранты требуют серьезной политики по их адаптации в принимающем обществе [Синяткин 2002].

Алжирское руководство понимает, что противодействие терроризму требует общих международных усилий. Французский институт исследований опубликовал списки ведущих международных террористических организаций, действующих на юге Алжира. Среди них организация «Аль-Каида» в исламском Магрибе (глава - Абд аль-Малик Друкдел), организация «Альморавид» (глава - Мохтар Белмохтар, основана в августе 2013 г.); организация «Эмират пустыни» (возглавляемая Джамалом Окашей) [Тауфик аль-Мадини 2017].

Чтобы противостоять угрозе терроризма и организованной преступности в международном масштабе, Алжир принял программу международного сотрудничества в области системы безопасности и подписал ряд соглашений, например Декларацию о стратегическом партнерстве между Алжиром и Россией, в которой особое внимание уделяется «сотрудничеству в борьбе с международным терроризмом, организованной преступностью, незаконным оборотом наркотиков и оружия», вопросам «экстрадиции по гражданским и уголовным делам», а также соглашениям о региональном сотрудничестве с соседними странами ${ }^{1}$.

Таким образом, самым большим препятствием на пути процесса национального примирения является выход терроризма на международный уровень. Несмотря на все гарантии, предоставленные государством, это не помешало деятельности новых международных террористических группировок в глобальных сетях и продолжению процесса вербовки террористов из соседних стран - Туниса, Мали и Нигерии, а значит, требуется улучшение координации действий международного сообщества по искоренению идеологии радикализма в сети Интернет, предотвращению вербовки новых членов и противодействию террористическим группировкам.

\section{Список литературы}

Балмасов С.С. 2017. Алжир начинает политику по снижению рождаемости. - Институт Ближнего Востока. 2017. 15 июля. Доступ: http://www.iimes. $\mathrm{ru} / ? \mathrm{p}=36424$ (проверено 22.08.2020).

Синяткин И.В. 2002. Североафриканская иммиграция во Франции: социокультурный и конфессиональный аспекты: автореф. дис. ... К.И.Н. М. РУДН. 22 с.

Тауфик аль-Мадини. 2017. Основные террористические группировки в

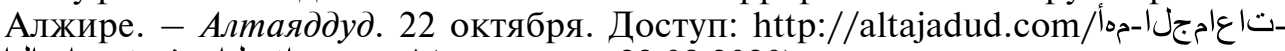

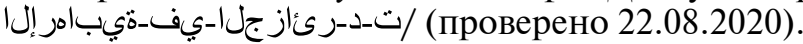

Ханун Н. 2008. Убедительные методы в алжирской письменной прессе: Хартия мира и национального примирения. С. 117-118. Доступ: https:bu.umc. edu.dz/theses/sc-information/AHAN2428.pdf (проверено 02.09.2020).

1 Декларация о стратегическом партнерстве между Алжиром и Россией от 4 апреля 2001 г. Доступ: http://www.russian-algeria.ru/publ/spravochnye_materialy/rossija_alzhir/ deklaracija_o_strategicheskom_partnerstve/32-1-0-221 (проверено 02.09.2020). 
USTINKIN Sergey Vasil'evich, Dr.Sci. (Hist.), Professor, Dean of the Higher School of Economics and World Politics, Dobroljubov State Linguistics University of Nizhny Novgorod (31A Minina St, Nizhny Novgorod, Russia, 603155; sv.ustinkin@gmail.com)

GASEM Akhmed, postgraduate student at Dobroljubov State Linguistics University of Nizhny Novgorod (31A Minina St, Nizhny Novgorod, Russia, 603155; ahmed.gacem@mail.ru)

RUDAKOVA Ekaterina Konstantinovna, Cand.Sci. (Pol.Sci.), Associate Professor of the Chair of International Relations and Political Science; Senior Researcher at Dobroljubov State Linguistics University of Nizhny Novgorod (31A Minina St, Nizhny Novgorod, Russia, 603155; ekaterina-rudakowa@mail.ru)

\title{
NATIONAL RECONCILIATION PROCESS IN ALGERIA: LEGAL AND DEMOGRAPHIC ASPECTS
}

\begin{abstract}
The article is devoted to the consideration of the stages of the regulatory legalization of the process of national reconciliation in the Republic of Algeria during the war for independence of 1991-2002. Initially starting with a national dialogue between the authorities and political parties in 1995 and holding the National Symposium in 1996, Algeria gradually created a legislative framework on security and counter terrorism, approved measures against former terrorists, adopted amendments to the Constitution, laws "On national reconciliation", "On civil harmony». Despite the cessation of the mass death of civilians and the preservation of the country's demographic potential, the serious consequences of the «Black Decade" are still felt in Algeria. International terrorist groups continue to operate in the south of Algeria, thousands of people are still wanted, and the victims of violence are awaiting for material compensation.
\end{abstract}

Keywords: Republic of Algeria, terrorism, national reconciliation, demography

РУДАКОВА Екатерина Константиновна - кандидат политических наук, доцент кафедры международных отношений и политологии, старший научный сотрудник Нижегородского государственного лингвистического университета им. Н.А. Добролюбова (603950, Россия, г. Нижний Новгород, ул. Минина, 31A; ekaterina-rudakowa@mail.ru)

\section{ДЕМОГРАФИЧЕСКИЙ КРИЗИС В ЕВРОПЕ: ТИПЫ ВОЗПРОИЗВОДСТВА НАСЕЛЕНИЯ}

\begin{abstract}
Аннотация. Анализ демографических показателей за 2018-2019 гг. свидетельствует, что страны Европы сегодня находятся под сильнейшим воздействием депопуляционных процессов. На основе анализа показателей рождаемости, смертности, иммиграции, эмиграции, численности абортов, фертильности населения, проведенного Евростатом и официальными статистическими службами европейских стран, автор определяет уровни естественного прироста, естественной убыли населения, миграционное сальдо. Полученные данные позволили выявить типы воспроизводства населения и подтвердить вывод, что для большинства стран Европы характерен суженый тип воспроизводства (смертность превышает рождаемость). И если в странах европейского «ядра» население восполняется за счет мигрантов и наблюдается незначительный прирост рождаемости, то в странах «периферии», придерживающихся политики «закрытых дверей» в отношении мигрантов, наблюдаются процессы демографического спада. Ключевые слова: Европа, депопуляция, демография, безопасность, население, миграция, аборт

